\title{
SOSIALISASI PENGENDALIAN KERUSAKAN LAHAN AKIBAT PERTAMBANGAN RAKYAT DI KABUPATEN BANTUL, PROVINSI DAERAH ISTIMEWA YOGYAKARTA
}

\author{
Oleh: \\ Arifudin Idrus ${ }^{1^{*}}$ dan Yuyun Prihatining Rahmah ${ }^{2}$ \\ 1'Departemen Teknik Geologi FT UGM \& Tenaga Ahli PSLH UGM \\ arifidrus@ugm.ac.id
}

\begin{abstract}
Abstrak
Kerusakan lahan terjadi di Kabupaten Bantul terutama diakibatkan oleh penambangan tanah liat pada sawah atau tegal produktif untuk pemenuhan bahan baku batu bata dan juga penambangan sirtu pada badan atau teras/bantaran sungai. Berlatarbelakang hal tersebut, Dinas Lingkungan Hidup (DLH) Kabupaten Bantul bekerjasama dengan Pusat Studi Lingkungan Hidup Universitas Gadjah Mada (PSLH UGM) menyelenggarakan Kegiatan Sosialisasi Pengendalian Kerusakan Lingkungan Hidup akibat kegiatan pertambangan rakyat yang dilakukan di seluruh kecamatan di Kabupaten Bantul. Metoda sosialisasi yaitu melalui Kegiatan Pendidikan Masyarakat berupa memberikan penyuluhan yang bertujuan meningkatkan pengetahuan, pemahaman serta kesadaran masyarakat terkait pentingnya pengendalian kerusakan lingkungan hidup untuk kehidupan yang lebih baik. Hasil kegiatan sosialisasi tersebut adalah pemahaman konsep-konsep penambangan yang baik dan benar (good mining practices), mulai dari tahap penyiapan lahan (pre-mining), tahap operasi penambangan dan tahap pasca penambangan. Pada tahap penyiapan lahan penambangan tanah liat misalnya harus mengamankan tanah pucuk (top soil), pada tahap menambangan perlu dilakukan dengan mempertimbangkan kesehatan dan keselamatan kerja (K3), meminimalisasi timbulnya berbagai dampak negatif terhadap aspek geofisik kimia biologi kesmas sosekbud yang berujung pada timbulnya konflik sosial, dan pada tahap pasca penambangan, lahan bekas tambang harus dilakukan penataan lahan (landforming), reklamasi dan revegetasi, serta direncanakan pemanfaatan lahan pasca tambangnya. Sosialisasi tersebut menunjukan tingkat pemahaman masyarakat terhadap resiko penambangan dan pengendalian kerusakan cukup baik $(>80 \%)$, sedangkan pemahaman terhadap good mining practices dan reklamasi pasca tambang berada pada tingkat sedang $(>70 \%,<80 \%)$.
\end{abstract}

Kata Kunci: Tambang rakyat, tanah liat, sirtu, kerusakan lingkungan, Kabupaten Bantul.

\begin{abstract}
The degradation of the land is observed in Bantul regency, which is mainly due to mining of clay in rice fields or productive land for the fulfillment of brick raw materials as well as sand-stone minng along the river or its terraces/riverbanks. On the basis of the background, the Environmental Agency of Bantul regency $(D L H)$ in collaboration with the Center for Environmental Studies of Universitas Gadjah Mada (PSLH UGM) held an Information Dissemination Program on Environmental Degradation Control due to public mining activities carried out in all sub-districts in Bantul regency. The method of dissemination is through Community Education activities in the form of providing counseling aimed at increasing knowledge, understanding and awareness of the community regarding the importance of controlling environmental degradation for a better life. The results of the information dissemination activities are understanding of good mining practices, starting from the stage of pre-mining, mining operations and post mining stages. At the stage of land preparation of clay mining, for example, must secure top soil, at the mining stage it needs to be done by considering occupational health and safety (K3), minimizing the emergence of various negative impacts on the aspects of geophysics, chemistry, biology, public health, socio-economic-culture which may lead to the social conflicts. In the post-mining stage, ex-mining land must be landformed, reclaimed and revegetated, and planning for the post-mining landuse. Level of understanding of public on mining risks and land degradation control is saticatory (>80\%), whereas those on good mining practices concept and post-mining reclamation of moderate $(>70 \%,<80 \%)$ was achieved.
\end{abstract}

Keywords: Public mining, clay, sand-stone, environmental degradation, Bantul regency

\section{PENDAHULUAN}

Jutaan hektar lahan sawah dan tegal (kebun) produktif di Indonesia disinyalir telah mengalami degradasi kesuburan, alih fungsi dan bahkan kondisinya terbengkalai (tidak dapat dimanfaatkan lagi) akibat dari kegiatan penambangan tanah liat, pasir batu dan lempung/tanah urug yang tidak memperhatikan kaidah-kaidah penambangan yang baik dan benar (good mining practices) (UGM, 2019). Walaupun sebagian kecil sudah mengantongi ijin pertambangan rakyat 
(IPR) dari pemerintah daerah, tetapi sebagian besar penambangan rakyat yang dilakukan oleh sekelompok orang tersebut belum memiliki ijin. Fenomena tersebut juga terjadi di Kabupaten Bantul, Provinsi Daerah Istimewa Yogyakarta. Lokasi kajian, Kabupaten Bantul terlihat pada peta (Gambar 1).

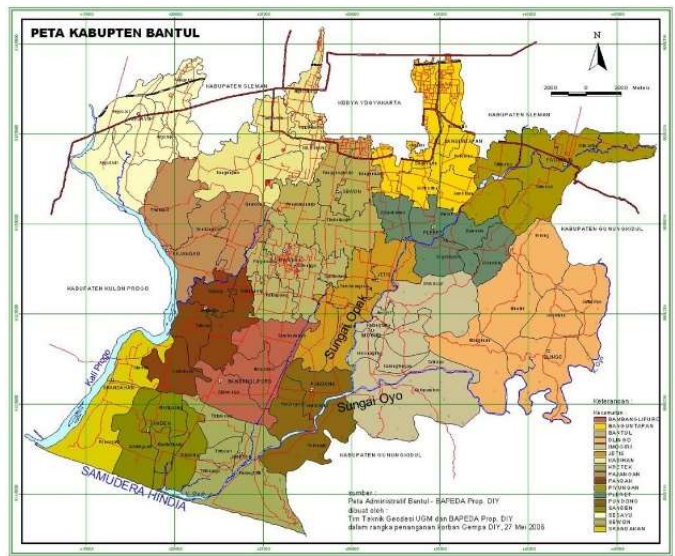

Gambar 1. Peta administrasi Kabupaten Bantul (Sumber: BAPPEDA DIY, 2006). Lokasi tambang tanah liat tidak dapat diplot di peta tetapi tersebar pada lahan sawah/tegal secara spot di beberapa kecamatan, sedangkan tambang sirtu umumnya di sungai seperti di Sungai Progo, Opak dan Oyo.

Berdasarkan data yang dipublikasi dalam Jurnal Riset Daerah, sekitar 11,689 Ha dari wilayah Lahan Pertanian Pangan Berkelanjutan (LP2B) Kabupaten Bantul pada tahun 2017 telah berubah menjadi areal penambangan tanah liat dan industri batu bata (UGM, 2019). Aktivitas penambangan untuk produksi batu bata semakin mengkhawatirkan, yang disebabkan kegiatan penambangan semakin meluas dan banyak dilakukan di kawasan lahan produktif. Penggalian tanah secara terus menerus membuat lapisan tanah subur menjadi semakin berkurang, bahkan hilang. Pasca tambang, lahan mengalami degradasi karena tereksploitasi secara besar-besaran.

Jenis tambang rakyat lain yang juga perlu mendapat perhatian adalah tambang pasir batu (sirtu) dan tanah urug di badan atau teras/bantaran sungai. Penambangan sirtu dan tanah urug pada sungai di Kabupaten Bantul antara lain teramati di badan dan bantaran Sungai Opak, Sungai Progo, Sungai Oyo, Sungai Code, Sungai Gajah Wong dan Sungai Salakan dan sebagainya dengan tingkat intensitas yang berbeda-beda.
Berdasarkan hal di atas, Dinas Lingkungan Hidup (DLH) Kabupaten Bantul bekerjasama dengan Pusat Studi Lingkungan Hidup Universitas Gadjah Mada (PSLH UGM) menggelar rangkaian kegiatan sosialisasi pengendalian kerusakan Lingkungan Hidup yang diakibatkan kegiatan pertambangan rakyat di beberapa kecamatan terpilih di Kabupaten Bantul. Tujuan dari kegiatan ini adalah memberikan dan meningkatkan pengetahuan, pemahaman serta kesadaran masyarakat terkait penambangan rakyat yang baik dan benar (good mining practices) dan pentingnya pengendalian kerusakan lingkungan hidup untuk kehidupan yang lebih baik dan keberlanjutan sumberdaya alam untuk pemenuhan kebutuhan generasi yang akan datang (sustainable development).

\section{METODE}

Untuk mencapai tujuan kegiatan Sosialisasi Pengendalian Kerusakan Lingkungan Hidup Akibat Penambangan Rakyat di Kabupaten Bantul tersebut, maka diterapkan metoda pelaksanaan berupa Pendidikan Masyarakat khususnya melalui Metoda Penyuluhan kepada Masyarakat. Metoda penyuluhan ini bertujuan untuk meningkatkan pengetahuan, pemahaman dan kesadaran masyarakat terkait topik kegiatan tersebut. Metode ini dilaksanakan melalui pemberian/paparan materi oleh beberapa narasumber/tenaga ahli yang berasal dari Pusat Studi Lingkungan Hidup Universitas Gadjah Mada (PSLH UGM) dan Dinas Lingkungan Hidup (DLH) Kabupaten Bantul, Provinsi Daerah Istimewa Yogyakarta.

Setelah pemaparan materi oleh para narasumber, porsi yang banyak adalah diskusi interaktif antara berbagai pihak yang hadir. Pihak yang hadir antara lain masyarakat penambang, pemilik lahan, aparat pemerintah daerah/kecamatan/desa/kelurahan/dusun, pihak polisi dan TNI, tokoh masyarakat serta pihak-pihak terkait lainnya (Tabel 1). Pada akhir acara dilakukan kuis sederhana untuk melihat tingkat pemahaman peserta. Sejauh ini dari rencana yang ada, sudah melakukan kegiatan sosialisasi di beberapa kecamatan antara lain Kecamatan Imogiri, Kecamatan Banguntapan dan Kecamatan Sedayu (Gambar 2).

Dikarenakan terbatasnya data publikasi penambangan rakyat sampai di level kecamatan dan desa/kelurahan, pada saat kegiatan tersebut digali lebih lanjut informasi 
jenis dan lokasi penambangan rakyat di setiap kecamatan/desa langsung dari peserta. Berbagai permasalahan yang timbul akibat penambangan rakyat tersebut didiskusikan dan dicarikan solusinya.

Tabel 1 Distribusi peserta sosialisasi pengendalian kerusakan lingkungan akibat pertambangan rakyat di Kabupaten Bantul.

\begin{tabular}{|c|l|r|r|}
\hline No. & Distribusi peserta & Jumlah $(\mathbf{n})$ & $\mathbf{\%}$ \\
\hline 1 & Masyarakat penambang & 78 & 46.43 \\
\hline 2 & Pemilik lahan penambangan & 36 & 21.43 \\
\hline 3 & Aparat pemerintah, TNI, polisi & 39 & 23.21 \\
\hline 4 & Tokoh dan masyarakat umum & 15 & 8.93 \\
\hline & Total & 168 & 100.00 \\
\hline
\end{tabular}

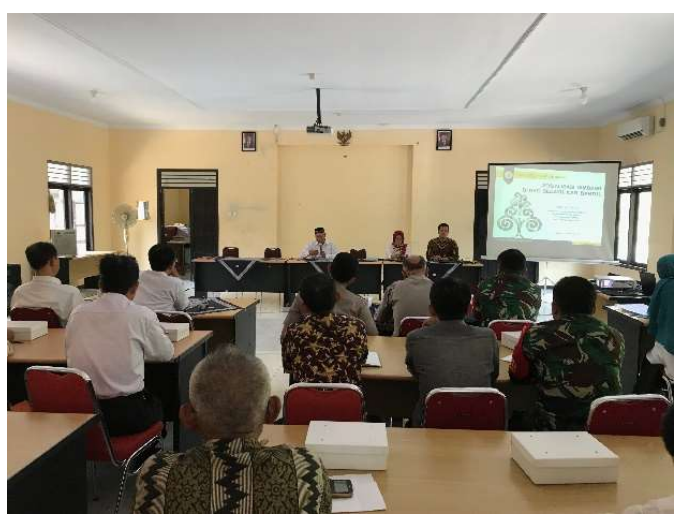

Gambar 2. Kegiatan sosialisasi pengendalian kerusakan lingkungan akibat pertambangan rakyat di Kecamatan Sedayu, Kabupaten Bantul

\section{HASIL DAN PEMBAHASAN}

\section{Konsep Good Mining Practices}

Dalam Undang-Undang Nomor 3 Tahun 2020 tentang Pertambangan Mineral dan Batubara disebutkan pertambangan adalah sebagian atau seluruh tahapan kegiatan dalam rangka penelitian, pengelolaan, dan pengusahaan mineral atau batu bara yang meliputi penyelidikan umum, eksplorasi, studi kelayakan, konstruksi, penambangan, pengolahan dan pemurnian, pengangkutan dan penjualan, serta kegiatan pasca tambang. Secara umum, bagan alir kegiatan pertambangan terlihat pada Gambar 3. Untuk menjamin optimalisasi pemanfaatan sumberdaya mineral dan kelangsungan lingkungan hidup, kegiatan pertambangan harus menerapkan konsep penambangan yang baik dan benar (good mining practices). Good mining practices merupakan seluruh proses yang dilalui dari awal sampai akhir harus dilakukan dengan baik dengan mengikuti standar yang telah ditetapkan, mengikuti norma dan peraturan yang berlaku sehingga dapat mencapai tujuan pertambangan dengan efisien. Salah satu bagian penting dari tujuan pertambangan adalah pembangunan berkelanjutan (sustainable development). Hal ini diartikan bahwa dalam setiap pengembangan dan pemanfaatan bahan tambang harus berkesinambungan dan/atau tergantikan dengan kegiatan ekonomi lainnya setelah pasca tambang.

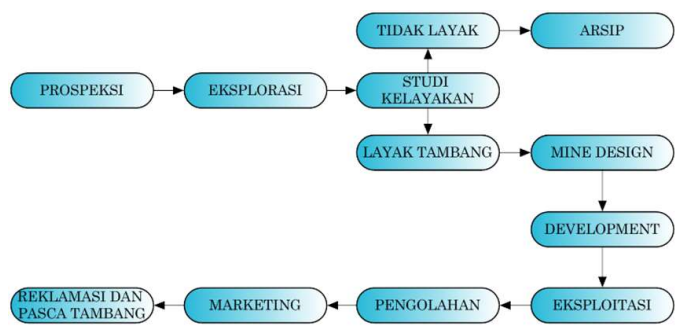

Gambar 3. Bagan alir kegiatan pertambangan (Idrus et al., 2009)

\section{Pertambangan Rakyat di Kabupaten Bantul}

Belum ada data yang terpublikasi dengan baik tentang jenis, kuantintas (sumberdaya) dan kualitas (data karakteristik) bahan galian serta jenis pertambangan rakyat di Kabupaten Bantul. Namun berdasarkan data primer yang digali dari peserta sosialisasi tersebut, maka jenis pertambangan rakyat (baik yang berijin maupun tidak berijin) meliputi misalnya di Kecamatan Imogiri terdapat tambang tanah urug, pasir (bantaran Sungai Opak) dan tambang kapur (batugamping); di Kecamatan Kasongan (dulu) terdapat tambang tanah liat untuk industri gerabah (sekarang dikenal sebagai Sentra Kerajinan Gerabah Kasongan) (Gambar 4); di Kecamatan Banguntapan terdapat tambang tanah liat, tanah urug dan sirtu [Sungai Gajak Wong, Sungai Opak (Gambar 5), Sungai Code dan Sungai Salakan)]; di Kecamatan Sedayu terdapat tambang tanah liat (sentra kerajinan gerabah di Argorejo) dan tambang sirtu di Sungai Progo. Jenis bahan galian dan tambang rakyat di kecamatan lain belum didata. Umumnya penambangan tanah liat dilakukan dalam skala kecil, tradisional dan memanfaatkan lahan sawah pribadi atau lahan sewa. Tambang sirtu di badan sungai sering dilakukan dengan alat-alat berat dan mesin sedot pasir. 


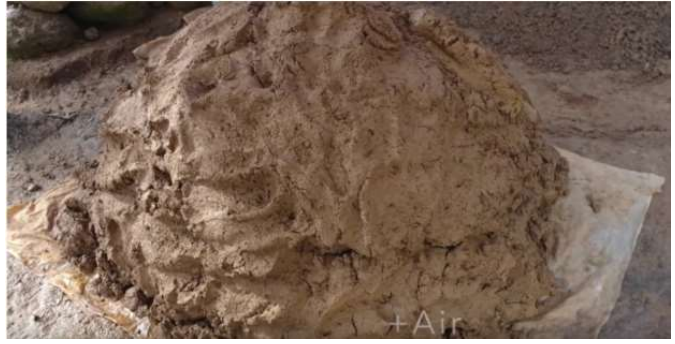

Gambar 4. Tambang tanah liat untuk kebutuhan industri gerabah di Kasongan, Kab. Bantul (KOMINFO, 2012)

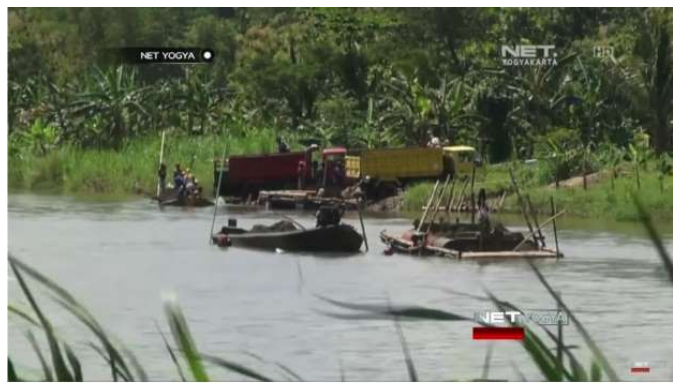

Gambar 5. Penambangan sirtu di bantaran Sungai Opak (NET YOGYA, 2017)

\section{Pengendalian Kerusakan Lingkungan}

Potret pertambangan rakyat Indonesia termasuk di Kabupaten Bantul sebagai berikut: merupakan alternatif kegiatan atau pilihan usaha informal, lapangan kerja yang dalam waktu singkat mampu menghasilkan cash money, status usaha banyak yang ilegal, dioperasikan oleh kelompok/komunitas tersendiri, memiliki mobilitas tinggi sehingga berdampak terhadap lingkungan sekitar. Selain itu, kesejahteraan penambang relatif tidak meningkat, ancaman kerusakan lingkungan dan memiliki potensi konflik dengan stakeholder lain. Olehnya itu dilema yang timbul dapat berupa pendapatan negara tidak ada, produktifitas rendah, teknik penambangan yang tidak memadai, rendahnya kepedulian terhadap keselamatan dan kesehatan kerja (K3) dan rentan terhadap kerusakan lingkungan (Gambar 6).

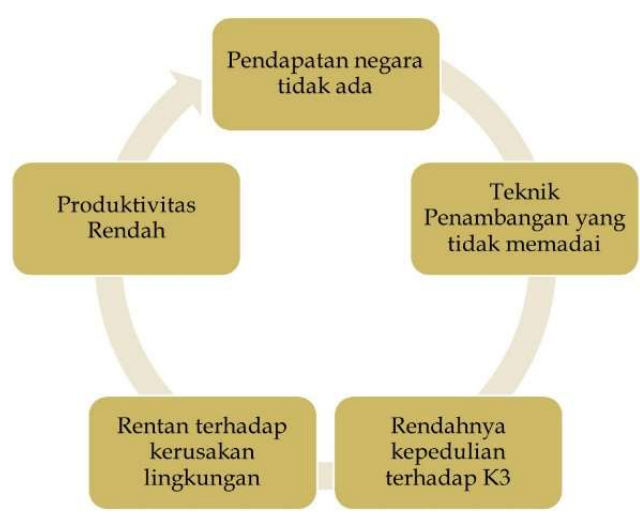

Gambar 6. Dilema pertambangan rakyat di Indonesia termasuk di Kabupaten Bantul (cf. Anonim, 2013)

Berdasarkan potret dan problematika yang timbul dari kegiatan pertambangan rakyat tersebut, maka perlu melakukan pengendalian terhadap kerusakan lingkungan dan K3 terutama pada penambangan tanah liat dan sirtu yang menjadi fokus bahasan tulisan ini melalui 3 (tiga) aspek utama yaitu menjamin keselamatan dan kesehatan kerja (K3) bagi penambang dan masyarakat sekitarnya, pengelolaan lingkungan hidup, serta reklamasi dan revegetasi pasca tambang.

Prinsip pengelolaan keselamatan dan kesehatan kerja (K3) pada pertambangan rakyat antara lain setiap pekerja harus terlindung dari kecelakaan dan penyakit akibat kerja, setiap kecelakaan dan penyakit akibat kerja ada penyebabnya, penyebab kecelakaan dan penyakit akibat kerja dapat dan harus dihilangkan/dicegah, serta setiap pekerjaan dapat dilakukan dengan selamat.

Pengelolaan lingkungan hidup menyangkut hal-hal antara lain penyelamatan tanah pucuk (top soil), menjaga kestabilan dinding tambang, membatasi penebangan pohon di sekitar tambang, membatasi laju pembukaan lahan, membatasi kedalaman penggalian dan tinggi timbunan, dan mengisi kembali (backfilling) kolong penambangan yang telah ditinggalkan. 

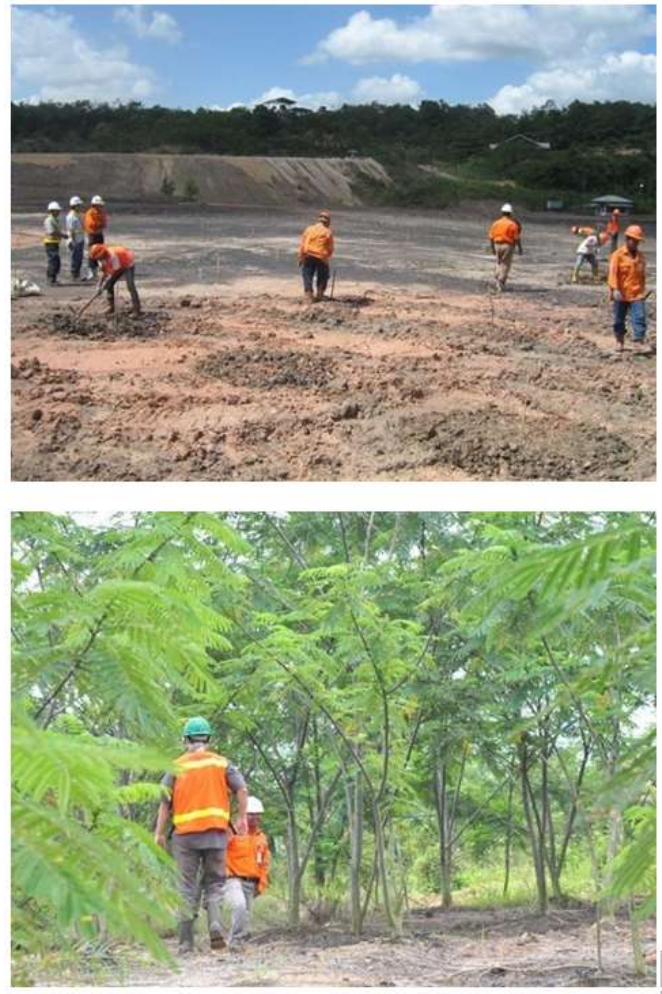

Gambar 7. Contoh penghijauan kembali lahan bekas tambah (atas) dengan tumbuhan yang sesuai dengan rencana peruntukan lahan pascatambang (bawah) (Rahma, 2014).

Aspek reklamasi dan pascatambang bagi penambangan rakyat antara lain penataan kembali lahan bekas tambang (landforming), penempatan kembali tanah pucuk (top soil) dan penghijauan kembali (revegetasi) dengan tumbuhan yang cocok sesuai peruntukan lahan pascatambang, contohnya seperti terlihat pada Gambar 7 (atas dan bawah).

Keberadaan pertambangan rakyat, merupakan upaya nyata pemerintah untuk memfasilitasi masyarakat penambang tradisional dan/atau menggunakan peralatan sederhana (UU No. 4 Tahun 2009). Untuk menjamin penerapan good mining practices pada pertambangan rakyat, maka syarat pertama seharusnya pertambangan rakyat tersebut memiliki ljin Pertambangan Rakyat (IPR). IPR seyogyanya harus berada dalam WPR (Wilayah Pertambangan Rakyat). Penetapan WPR dilakukan oleh Bupati/Walikota setelah berkoordinasi dengan DPRD. Tempat kegiatan tambang rakyat yang sudah dikerjakan diprioritaskan untuk ditetapkan sebagai WPR sebagai wadah kegiatan tambang rakyat. Kriteria
Menetapkan WPR mengacu pada PP No.23 Tahun 2010.

Sebelum menerbitkan IPR pada wilayah pertambangan rakyat, wajib menyusun rencana reklamasi dan rencana pascatambang untuk setiap wilayah pertambangan rakyat. Rencana reklamasi disusun berdasarkan dokumen pengelolaan lingkungan yang telah disetujui dan pemerintah daerah menetapkan rencana reklamasi dan rencana pascatambang untuk pemegang IPR. Pemegang IPR bersama dengan pemerintah daerah wajib melaksanakan reklamasi dan pascatambang sesuai dengan rencana reklamasi dan rencana pascatambang.

\section{SIMPULAN DAN SARAN}

\section{Simpulan}

- Kerusakan lingkungan akibat kegiatan pertambangan rakyat di Indonesia, termasuk di Kabupaten Bantul, Provinsi Daerah Istimewa Yogyakarta sudah cukup mengkhawatirkan, sehingga Dinas Lingkungan Hidup (DLH) Kabupaten Bantul bekerjasama dengan Pusat Studi Lingkungan Hidup Universitas Gadjah Mada (PSLH UGM) mengadakan kegiatan Sosialisasi Pengendalian Kerusakan Lingkungan akibat Pertambangan Rakyat tersebut khususnya tambang tanah liat dan sirtu.

- Kegiatan sosialisasi tersebut telah (berhasil) memberikan dan meningkatkan pemahaman, pengetahuan dan kesadaran bersama berbagai pihak terkait (masyarakat penambang, penyewa lahan, tokoh masyarakat, dinas terkait, Kepolisian dan TNI serta aparat pemerintah dusun, desa/kelurahan dan kecamatan) tentang pentingnya penambangan yang baik dan benar (good mining practices). Tingkat pemahaman peserta/ masyarakat terhadap resiko penambangan dan pengendalian kerusakan lahan akibat penambangan sekitar $80 \%$ (cukup baik).

- Pengendalian kerusakan lingkungan hidup terutama akibat kegiatan penambangan tanah liat dan sirtu di Kabupaten Bantul dapat melalui 3 (tiga) mekanisme yaitu menjamin keselamatan dan kesehatan kerja (K3) bagi penambang dan masyarakat sekitarnya, pengelolaan 
lingkungan hidup, serta reklamasi dan revegetasi pasca tambang.

- Pertambangan rakyat seharusnya memiliki ijin pertambangan rakyat (IPR) sehingga dapat memberikan pemasukan bagi negara. Pemerintah daerah berkewajiban membina dan melaksanakan reklamasi dan pascatambang.

\section{Saran}

- Kegiatan sosialisasi pengendalian kerusakan lingkungan hidup akibat pertambangan rakyat tersebut disambut antusias oleh masyarakat, maka direkomendasi untuk dilanjutkan ke kecamatan-kecamatan lain, bila perlu sampai pada level desa/kelurahan dan komunitas penambang dan pemilik (penyewa) lahan.

- Sejauh ini belum diketahui dengan akurat penyebaran dan luasan daerah bekas tambang khususnya tambang tanah liat yang terabaikan (abandoned), sehingga dalam rangka revitalisasi dan reklamasi diperlukan pemetaan dan inventarisasi dengan seksama.

\section{DAFTAR PUSTAKA}

Anonim, 2013, Konsep Tambang Rakyat di Indonesia Berdasarkan Undang-Undang No. 4 Tahun 2009 dan Permasalahannya, Bahan Paparan di Hotel Le Meridien, Jakarta, 15 Agustus 2013

BAPPEDA DIY, 2006, Peta administrasi Kabupaten Bantul 2006, Kerjasama BAPPEDA DIY dengan Jurusan Teknik Geologi FT UGM

Idrus, A., 2012, Sumberdaya Mineral untuk Rakyat, Chapter Buku IImu untuk Rakyat, Gadjah Mada University Press, 169 hal.

Idrus, A., Warmada, I.W., Setidjaji, L.D. 2009, Eksplorasi Sumberdaya Mineral, Bahan Ajar, Departemen Teknik Geologi FT UGM, Unpublished, 96 hal.

KOMINFO, 2012, UKM Melalui Kerajinan Gerabah, Kasongan, Bantul, Yogyakarta, https://www.youtube.com/watch?v=qREj0 ORpLK4 (diunduh tanggal 19 Juni 2019)

NET YOGYA, 2017, Polemik Penambangan Sirtu di Bantaran Sungai Opak, Bantul, https://www.youtube.com/watch?v=Qrvm0 $\underline{\mathrm{Rx} 2 p n 8}$ (diunduh tanggal 19 Juni 2019)
PP No.23 Tahun 2010 tentang Pelaksanaan Kegiatan Usaha Pertambangan Mineral dan Batubara

Rahma, C., 2014, Inovasi Teknologi Reklamasi Lahan Pascatambang Tanpa Penambahan Tanah Pucuk https://www.indonesiana.id/read/23732/ino vasi-teknologi-reklamasi-lahanpascatambang-tanpa-penambahan-tanahpucuk\#Kqy7gm672uulGkXE.99 (diunduh tanggal 20 Juni 2019)

UGM, 2019, Sawah di Bantul Rusak Akibat Tambang Batu Bata, Berita UGM Tanggal $10 \quad$ April 2019, https://ugm.ac.id/id/berita/17822sawah.di.bantul.rusak.akibat.tambah.batu. bata (diunduh tanggal 18 Juni 2019)

UU No. 3 Tahun tentang Pertambangan Mineral dan Batubara 